\title{
Toward a Theology of Engagement A study of Komunitas Tritunggal Mahakudus as a Field of Action
}

\author{
Martinus Joko Lelono ${ }^{\text {a,1 }}$ \\ Fatimah Husein ${ }^{b, 2}$ \\ Leonard Chrysostomos Epafras c,3 \\ a. Doctoral Student in Inter-Religious Studies Program, \\ in the Gadjah Mada University Graduate School \\ b. Sunan Kalijaga State Islamic University, Yogyakarta, Indonesia \\ c. Universitas Kristen Duta Wacana, Yogyakarta, Indonesia \\ 1.martinusjoko@gmail.com \\ 2.fatimahhusein@yahoo.com \\ 3.leonard.epafras@mail.ugm.ac.id
}

\section{Abstract:}

In his Apostolic Exhortation, Evangelii Gaudium (The Joy of the Gospel), for the Bishop, Clergy, Consecrated Persons, and the Lay Faithful on the Proclamation of the Gospel in Today's World, Pope Francis emphasized on the need to approach young people, either to evangelize and educate them or the urgency to exercise greater leadership (Art. 106). Pope Francis encouraged the Catholic Church to regard these youth do not only as object but also subject of evangelization. This invitation is not a new invitation of the Catholic Church. Pope John Paul II regarded that the Catholic Church required a more profound evangelization effort. John Paul II raised this idea on March 9, 1983, in front of Latin American bishops in Port-au-Prince, Haiti. He emphasizes on the newness in expression, fervor, and methods. In Indonesia, Komunitas Tritunggal Mahakudus, one kind of Catholic Charismatic Renewals, welcomed this encouragement of John Paul II. This community puts intensive programs to engage the youth in the evangelization work. With a well design programs, they achieve voluntary youth involvement. This community succeeds in providing the youth with personal engagement and communal community goal. The present paper is an analysis of a negotiation process of Komunitas Tritunggal Mahakudus toward the present situation of the Catholic Church in Indonesia. In the perspective 
of post-modern with its doubt on meta-narration, this article proposes a plurality of the evangelization efforts. The perspective of Social Action Field theory coined by Neil Fligstein and Doug McAdam, with its idea of providing a group of people with a field of action, enables the analysis upon Komunitas Tritunggal Mahakudus enriching the methods of evangelization. Evangelization is not one-time process, but rather a continuous process of producing a field of action.

\section{Keyword:}

The Komunitas Tritunggal Mahakudus, Youth Engagement, Social Action Field, Voluntary Involvement.

Komunitas Tritunggal Mahakudus (Literally translated to The Holy Trinity Community, hereafter KTM) was established on January $11^{\text {th }}$, 1987, by Fr. Yohanes Indrakusuma, O.Carm, as a local Catholic Charismatic Renewal (hereafter CCR). ${ }^{1}$ Within the Catholic Church in Indonesia, KTM has numbers of uniqueness. The first is the mission to have $100 \%$ Charismatic, and also 100 \% Catholic. In history, the Charismatic movement have some intention to have a flexible religious expression, while in the Catholic Church that presumed strict religious normativity. In this condition, this community negotiated for public acceptance within the Catholic Church, without losing their Charismatic identity. The second is its locality since this community originally begun in Indonesia with a specific adaptation of the Charismatic movement. While there is a Charismatic community that embedded toward the local Church community (Parish and diocese), this community has its hierarchy of leadership. The third, this community is embedded toward CSE, a community of priests and Putri Karmel, a community of nuns because these three communities founded by the same person. They are supporting each other with evangelization as their shared goal. The fourth, this community is a reaction toward the influence of the Pentecostal movement within the CCR. Therefore, this community emerged as a critic for the earlier CCR community and pretend to be a community with a better loyalty toward the Catholic Church.

Komunitas Tritunggal Mahakudus, Program Pembinaan Anggota Buku Pegangan I (Komunitas Tritunggal Mahakudus, n.d.), 11. 
KTM has evangelization, bringing the Good News into all walks of life, and through its influence transforming humanity from within, ${ }^{2}$ as their primary goal. This community emphasized explicitly on the proclaiming Gospel openly and invited people to the repentance that could transform their life. ${ }^{3}$ KTM confirms this mission as their primary goal on the formulation of their mission, "In the power of the Holy Spirit, to experience and to live the loving and saving presence of God till the union of love and to bring others to the same experience." They emphasize both personal experience of God's love and the invitation to proclaim His presence. ${ }^{4}$ In doing its mission, KTM prefers to do what they called as direct evangelization rather than indirect evangelization. This indirect evangelization could be understood as the evangelization without proclamation through social works and charity actions (school, hospital, or orphanage) as commonly practiced in the Catholic Church. KTM criticizes this method since this kind of evangelization mostly fits into the agrarian society. ${ }^{5}$ On the implementation of direct evangelization, KTM focuses on personal engagement. Instead of doing social engagement through school, orphanage or hospital, KTM focuses on spiritual service. It includes services of (a) prayer training; (b) adoration training; (c) bible study; (d) evangelization; (e) family service; (f) youth service; (g) spiritual healing. ${ }^{6}$

This lay engagement is a follow-up of the Second Vatican Council (1962-1965) invitation for the laity participation in the evangelization. As a turning point of the Catholic Church on looking at the modernizing world, the Second Vatican Council looks at the lay participation in a new perspective. The Catholic also engage laypeople as a partner of evangelization for clergies. ${ }^{7}$ The engagement of the laypeople to have a collab-

2 Paul VI, “Evangelii Nuntiandi ('On Evangelization in the Modern World'),” Apostolic Exhortation, 1975, p. Art. 18.

3 Komunitas Tritunggal Mahakudus, Latihan Pelayan Sel Komunitas (Cianjur: Sekretariat KTM Pusat, n.d.), 3.

4 “Komunitas Tritunggal Mahakudus | Our Vision \& Spirituality," accessed March 12, 2019, http://www.holytrinitycarmel.com/our-spirituality/.

5 Yohanes Indrakusuma, Menggereja 'Ala' KTM, (Cianjur: Pertapaan Shanti Bhuana, n.d.), 25-26.

6 Statuta Komunitas Tritunggal Mahakudus (Cianjur: Komunitas Tritunggal Mahakudus, n.d.), $12-$ 13.

7 Stephen J Denig and Anthony J Dosen, "The Mission of the Catholic School in the Pre-Vatican II Era (1810-1962) and the Post-Vatican II Era (1965-1995): Insights and Observations for the New Millennium," Catholic Education: A Journal of Inquiry and Practice 13, no. 2 (2009): 141. 
oration for the work of evangelization is known as New Evangelization. Pope John Paul II raised this idea on March 9, 1983, in front of Latin American bishops in Port-au-Prince, Haiti. He emphasizes the newness in expression, fervor, and methods. He spoke in the 500th anniversary celebration of Europe's encounter with the Americans, simultaneously as a preparation for the new millennium. This Pope re-emphasized his speech at the fourth World Youth Day in 1989, "It is not enough to discover Christ-you must bring him to others! ... You must have the courage to speak about Christ, to bear witness to your faith through a lifestyle inspired by the gospel." ${ }^{8}$ Pope regards evangelization as an obligation for each Catholic. This speech based on the fact of the continuous reduction of Catholic hegemony, together with the increasing number of Protestants, especially in Latin America. ${ }^{9}$ He underlined the need for a new evangelization to have new conversion and to improve the faith of "Nominal Catholics." 10

In the Latin America context, this New Evangelization became the most effective response to Pentecostal Churches. Several scholars realized that they miscalculated on looking at the growth of Protestantism in Latin America. In 1990 David Stoll, an American Anthropologist, predicted that in 2010, there would be five or six nations with Protestant Majority. ${ }^{11}$ R. Andrew Chesnut argued that the Pentecostal Churches would remake the socio-religious landscape in Latin America. ${ }^{12}$ This prediction is over-optimistic. Up to 2005, Pentecostal Churches could only reach a small number of population. Out of 33 countries, there are only four countries in which Pentecostal could reach a third of their popula-

8 Roger Finke and Rodney Stark, The Churching of America, 1776-2005:Winners and Losers in Our Religious Economy (Rutgers University Press, 2005), 35.

9 The Catholic Church put attention on this issue since even Pope John Paul II that well-known as the one who promotes religious tolerance firmly criticizes them (Evangelical sects) as "Voracious Wolves." Finke and Stark, 35.

10 Michael J McCallion and David R Maines, "Representations of Faith and the Catholic New Evangelization,” New Theology Review 22, no. 1 (2009): 60; Anna L Peterson and Manuel A Vásquez, "The New Evangelization in Latin American Perspective," CrossCurrents (1998): 315-316.

11 David Stoll, Is Latin America Turning Protestant?:The Politics of Evangelical Growth (Univ of California Press, 1990); Finke and Stark, The Churching of America, 1776-2005:Winners and Losers in Our Religious Economy, 42.

12 R Andrew Chesnut, Competitive Spirits: Latin America's New Religious Economy (Oxford University Press, 2003), 3. 
tion. ${ }^{13}$ Both of them did not consider that in the places where the Protestant influence more, Catholics become more energetic on defending their faith. In his observation toward 18 Latin American nations, David Stoll found that in the competition with Protestantism, the Catholic in Latin America becomes stronger. ${ }^{14}$ Within this context, the CCR takes a distinguished contribution. In Latin America, the CCR becomes an adequate competitor for the Pentecostal movement. They are well known as the most enormous and most alive Catholic lay movement in most countries $^{15}$

With a different context, Fr. Yohanes takes advantage of the participation of laypeople in the evangelization. KTM builds a structure of the community that enables them to attract people. In conducting his community, Fr. Yohanes learned from the home cell system of the Full Gospel Central Church in Seoul, established by Dr. Paul Yonggi Cho. ${ }^{16}$ Cho offered the Idea of home cell community. It is a small group that consists of people who know each other and support one another. They conduct a weekly meeting and commit of community life. Every cell consists of not more than fifteen members. ${ }^{17}$ They aim to have a community with a deeper relationship that supports each other. When Fr. Yohanes took over the idea of cell-based Community, he could not directly translate the idea since he did not establish a new church but a community within the Catholic Church. Within this context, Fr. Yohanes together with his three communities did a politic of recognition in order to be accepted as a part of the Catholic Church.

The cell community meeting is considered as the main activity carried out by the KTM members. This cell community meeting emphasizes the personal relationship with God and their fellow KTM members. Each

13 Stoll, Is Latin America Turning Protestant?: The Politics of Evangelical Growth; Finke and Stark, The Churching of America, 1776-2005:Winners and Losers in Our Religious Economy, 42.

14 Finke and Stark, The Churching of America, 1776-2005:Winners and Losers in Our Religious Economy, $39-40$.

15 Chesnut, Competitive Spirits: Latin America's New Religious Economy, 66.

16 Yong-gi Cho et al., Successful Home Cell Groups (Logos International, 1981).

17 Cho describes his church as both the biggest and the smallest church community in the world. It could be count as the biggest since their members are more than 150.000 people, but at the same time, it is the smallest since all members are divided into small communities. Since they are separated into small communities, this kind of community gives more opportunities for those who wish to be involved in the ministry. Cho et al., 46-48. 
cell consists of 4-14 members. ${ }^{18}$ This cell community was built as an instrument to multiply the community. Each cell with members more than 14 should prepare themselves to be divided into two cells. The first one would be led by the servant of the cell, while the vice servant leads the second one. Both of them need to choose their vice to prepare for multiplication. This multiplication enables them to reach their fellow Catholics and those who do not know Christ. ${ }^{19}$ Instead of this multiplication, cell-based community contributes as a community that could support to each other with community of prayer. Cell community is more efficient compare to the traditional churches since they could optimize the role of member. Furthermore, they could also become a community of prayer in which there have a "sense of belonging". With small number only, they could understand one another and pray to each other with their personal life context. ${ }^{20}$ Indeed, in the KTM context, these processes do not always run smoothly, but they could reach more and more people. In 2015, they claimed to have 10.000 members, while in 2019 , they reach 11.852 members. ${ }^{21}$

KTM is a community that consists of cells. The whole community is divided into cell communities with a cell servant, assisted by one representative as the leader. Each around five cells build one Region, under the leadership of a Region Servant, assisted by his Board. Every five regions could be one District, under the leadership of District Servants and their Councils. Some Districts are collected into one province, under the leadership of the provincial servants assisted by a council. Every level of leadership works under the servants of a higher level. They determine the status of the community in the lower level with the approval of the Board. Provincial Ministers from various regions and countries are responsible for the Community Public Servants. The Community Public

18 Yohanes Indrakusuma, Menggereja 'Ala' KTM, 31; Komunitas Tritunggal Mahakudus, Program Pembinaan Anggota Buku Pegangan I, 22.

19 Yohanes Indrakusuma, Dipanggil UntukYang Luhur Dan Mulia (Cianjur: Pertapaan Shanti Bhuana, 2009), 356-357.

20 Ralph W. Neighbour, Jr., Ke Mana Kita Harus Melangkah? (Yayasan Metanoia Publishing, 1997), 9-10.

${ }^{21}$ Rm. Yohanes Indrakusuma, O.Carm., 'KTM di dalam Gereja, Suatu Bentuk Baru Perwujudan Komunitas Basis,' Menggereja 'ala' KTM, Pertapaan Shanti Bhuana, (Jawa Barat), pp. 36-42; The KTM central secretariat at the Cikanyere Carmelite Monastery; http:/ / www.holytrinitycarmel.com/baru-buku-panduan-anggota-pelayan-ktm. 
Servants are responsible for Primary Shepherd. ${ }^{22}$ This cell community enables KTM in contact with each other to keep their loyalty.

On doing their evangelization, KTM uses two ideas of evangelization that enable them to engage more people: Oikos Evangelization and Ad Gentes Evangelization. Oikos Evangelization (literally means family evangelization) is an effort to evangelize personal relationships: family, workers; business relations; friends, and neighbors. ${ }^{23}$ This Oikos Evangelization is a natural way to have a connection with people. Fr. Yohanes believes that this method brings better benefits compare to indirect evangelization because KTM could have a more intense personal influence. ${ }^{24}$

The Ad Gentes Evangelization (literarily means evangelization to nations) emphasizes on the evangelization toward people from other places. KTM divided this evangelization toward two categorizations: evangelization and re-evangelization. Evangelization is a process of reaching people from other religions to be Catholic. They have one Ad Gentes evangelization area in the Merapu Mountains in South Kalimantan among people with local religion, the Kaharingan. Re-evangelization is a process to evangelize what they call as nominal Catholic. They stay with the Catholic community and encourage them to have an active participation in religious services and form a new KTM cell community. ${ }^{25}$

In conducting this Ad Gentes Evangelization, KTM has exclusive members, the volunteers. They are KTM members who dedicate their time to go to the mission areas. In 2006, KTM offered four-month program in the mission area. Nowadays, the program lasts for at least one year. The mission place could be in the rural area, or to do a mobile volunteer (visiting the KTM cell community all over the world). In the area, they do an evangelization mission either to understand the Catholic faith better or even choose to have a conversion to Catholic for non-Catholic. ${ }^{26}$

22 The Information is the resume of the explanation in the Secretariat of Center of KTM and Statuta Komunitas Tritunggal Mahakudus.

23 Komunitas Tritunggal Mahakudus, Latihan Pelayan Sel Komunitas, 8-9.

24 Rm. Yohanes Indrakusuma, O.Carm., 'KTM di Dalam Gereja, Suatu Bentuk Baru Perwujudan Komunitas Basis,' Menggereja 'ala’ KTM, Pertapaan Shanti Bhuana, (Jawa Barat), p. 29.

25 ..., Menggereja 'ala’ KTM, Pertapaan Shanti Bhuana, (Jawa Barat), pp. 22-35.

26 Angelika Dewi Wijayanti Supriyanto, May 18, 2018. 


\section{The Youth Engagement}

As a community of evangelization, KTM engages people to support their mission. The first challenge is how to engage new members. Out of several works for engaging people, one distinguished program is the youth engagement. This community is well known for its annual youth spiritual camp and also special service upon the youth cell communities. Instead of providing them with a community, KTM also involves the youth for the evangelization.

The idea to hold youth spiritual camp started from the Java-Bali youth convention held in 1981 in Malang. Fr. Yohanes was the moderator and coordinator of the Charismatic Service Agency in Diocese of Malang. After several groups failed to hold a similar event, there was a desire to hold a youth spiritual camp. Then the word Kemping Rohani (Spiritual Camp) was chosen without directly involve charismatic groups. One year after its establishment, KTM held the first Youth Spiritual Camp in 1988. At that time, there were 120 students from the third class of junior high schools to University students. In the following years, the participants increased in number: 250 in the second year, 450 in the third year, and 700 in the fourth year. Because of this increasing number, KTM divided the camp into two groups. In 1995 the number reached 2.375 youth, while in 1996, there were 2.450 people registered. Because of the political situation in 1997 to only 1998 , there was a reduced number of participants. In 1998 it was even eliminated due to an impossible situation. In 1999 the camp was held in two sessions with 2.265 participants in total.

Nowadays, there are three categories of youth spiritual camp, namely: camp for children of fourth to seventh grade, eighth to twelfth grade, and 'university students and young workers.' It is not merely a camp, but indeed, this camp is a retreat. Fr. Yohanes said, "This camp is an event to attract the youth. It is a retreat held in the camp form. We conduct a suitable method for the youth, even if we give them the contents of the retreat. There are prayers in the Charismatic rite, but also silent prayers." ${ }^{27}$ In the retreat, they give the two retreats that are obligate for new KTM members: The Retreat of the New Life in the Spirit and The Retreat on the healing of luka batin (spiritual torment). In the session on a New Life in the Spirit, they encourage the youth to have a reflection on personal sins, and opportunities for repentance.

27 Fr. Yohanes Indrakusuma, "Interview on Komunitas Tritunggal Mahakudus," August 8, 2019. 
They convinced the youth that the spiritual torment that could harm their future, therefore they need to release it. They suggested them to have a new life, an awareness to forget their mistakes and forgive those who have done wrong. They spent three hours in this session. On the silence, Sister and Priest, who led the session, helped them to look at their pain. Some have problems with their parents, siblings, teachers, girlfriends, pastors, or specific people. They emphasized on the need to heal their spiritual torment and forgive their own mistakes.

In the third-day, they provide them with a new insight into a life-changing. There was the formation of self-acceptance. These youth were aware of their personal lack. It could be a situation of about to be aborted or the divorce of parent. They criticized the addiction toward pornography that leads them to addiction to masturbation and free sex, doing abortion, and having less respect toward themselves. The priest convinces them not to be addicted to drugs or alcohol. After various lengthy expressions, the program continued with the feet washing program. About twenty people were ready to represent many figures. They sit in a chair. They come from various levels of ages to represent parents, young people, women, men. Several of them represent persons with various professions. The camp participants choose one of them. They could choose a person who represents their mother, father, or sibling. The point is that they could have a reconciliation with the person that has a problem with them, by wash the figurant feet. Each participant comes to a figurant, told him/her about their problem. After they wash each other's feet, the program ended with a prayer from the figure to the child. They have an opportunity to make a confession that extended with a personal consultation. On the same day, they will have an opportunity to experience two essential things: a class on Speaking in Tongue and the outpouring of the Holy Spirit. This session is a session that gives a Charismatic characteristic explicitly.

At the end of the program, they conduct a "Misa Panggilan" (Vocational Mass). Within this mass, the priest and nuns convince these youth that every single person has their vocation. Several of them declare their wish to be a priest, nun, or a brother. There are several of them who give testimony about the camp. One of them shared how his faith was growing in the camp. While a boy told about her family problems, he said that he found the purpose of life to "unite with God." At the end of the mass, the priest invites Camp participants to join a community in the Church. He said that there is no other way to have an excellent religious life without 
living in the community. They may choose any religious community, but for that moment, they have a promotion of KTM.

\section{A Process of Recognition}

The unique aspect of KTM is the fact that this community could engage the need of the youth and encourage them to run for a work of evangelization. The Strategic Action Field (SAFs) enables us to grasp the dynamic of this community. This theory is a theory about collective actions within a social structure. It is a system in which actors within a social structure, either individually or collectively, relate to each other. A sharing understanding of the purpose of the field bridges their social relationships.

On the one hand, all social structure is a part of SAFs on their external dynamic, but on the other hand, they consist of SAFs within their internal dynamic. According to this theory, each SAF is always in correlation with one another. Therefore in its implementation to analyst a power relation in each field, SAF is always in the plural form (SAFs). ${ }^{28}$ Fligstein and McAdam divide the actors within SAF into three categories: incumbent, challenger, and the governance unit. The incumbents are those with the highest domination within a field. Usually, they control the interest of the group. ${ }^{29}$ The challengers hold less power domination within the field, and the incumbent usually dominates them. They are waiting for an opportunity to induce their alternative vision. The third actor is known as the governance unit. They are a part of a field to maintain stabilization. They manage the rules of the field and facilitate the functioning and reproduction of the system. ${ }^{30}$ In front of the contestation between incumbents and challengers, these governance units do not play a neutral role but predominantly support the incumbent. They usually maintain functioning and reproduction. ${ }^{31}$

As a unit of collective action in society, SAFs theory explains power contention among social actors within a particular social structure. This theory explains the way new meso-level social orders are produced and

28 Neil Fligstein and Doug McAdam, “Toward a General Theory of Strategic Action Fields," Sociological theory 29, no. 1 (2011): 3.

29 - Ibid., 5.

30 Neil Fligstein and Doug McAdam, A Theory of Fields (Oxford University Press, 2015), 13-14.

31 Ibid., 77. 
maintained. In the KTM context, KTM did not emerge in the free space, but rather in the connection with the Catholic Church and also the CCR that already exist. This theory enable us to explain that the relation within a social structure is not always fixed, but rather in the contention.

On producing new alternative logic or reproducing the old logic of field, this theory notices to the role of a skilled strategic actor(s). They are the actor with a particular ability to maintain or challenge the existing logic. That is why they exist both in the incumbent or challenger part. Their main task is to formulating specific ideas that strengthen the position of incumbent or challenger. On the incumbent's side, they maintain the domination either by keeping the old logic or offer the new one. On the challenger's side, their task is to construct a new logic of action to challenge the one to belong to incumbents. ${ }^{32}$ Their main task is to influence people to share their logic. At least four actions enable a skilled strategic actor(s) to increases their authority: framing, agenda-setting, brokering, and 'robust action.' These actions provide meaningful proposals that appeal to a large number of actors ${ }^{33}$ Framing means providing new logic of structures to unite people with diverse logical thoughts to share a common understanding. Skilled strategic actor(s) does agenda-setting to convince others that they need to do collective action(s) to achieve a specific goal. ${ }^{34}$ Brokering means understanding the situation of a particular community in a critical situation and offering a new collective identity and logic of action.

Upon all activities in the KTM, the skilled strategic actor is Fr. Yohanes. This identification is the result of the observation that almost all respondents refer to Fr. Yohanes for certain activities they do. He is the center of this community. In his biography, Fr. Yohanes mentioned that he was looking for religious expression that matches to the spirituality of the Catholic. He earned doctorate degree in Catholic spirituality. He was a Carmelite that so familiar with the contemplative life, but he encountered the Charismatic spirituality that touches his heart. In order to deepen his spiritual life, he learned from Zen in Japan, spiritual life in Thailand, and went to India to learn about meditation. Finally, he decided to live as a solitary (ascetic), a unique way of life among Carmelite. He spent several time to ask for a license. He was about to stay alone in

32 Neil Fligstein, “Social Skill and the Theory of Fields," Sociological Theory 19, no. 2 (2001): 108.

33 Fligstein and McAdam, A Theory of Fields, 51.

34 Fligstein, "Social Skill and the Theory of Fields," 114. 
Ngroto before he moved to Ngadireso in Malang, but several nuns asked him to give them retreat. Several girls came and asked him to accept them as his companion. Later on, several boys come and did the same. That is the starting point for them to have Putri Karmel in 1982 and CSE in 1986. KTM come later in 1987. Within these three communities, Fr. Yohanes encouraged the Carmelite Charismatic Renewal spirituality. He found that both of them are a match combination. ${ }^{35}$

In his book about CSE and Putri Karmel, Fr. Yohanes notes that KTM emerged as a place in which CSE and Putri Karmel multiply their human resources. KTM is essential to support CSE and Putri Karmel for their evangelization work. He said,

"As we have already many kinds of work, we acknowledge that we need a lack of human resources. Therefore we need to have an appropriate strategy... It is good that we already have KTM. From the first time, we plan that they can multiply themselves with their cell multiplication.... The cell multiplication is an effective evangelization instrument, either among Catholic or among people out of the Catholic Church, those who never know about Jesus." 36

To some extent, KTM becomes the soldier for CSE and Putri Karmel to enrich their work of evangelization. KTM conducts several categories of cell communities as the center of the whole community: the youth cell communities, and the adult cell communities. This journal focuses on youth cell communities. In order to provide the youth with religious youth culture, Fr. Yohanes and KTM engaged four actions in order to build a Social Action Field. These actions provide this youth with a new sharing logic in living the Catholic Faith.

\section{Social Framing and Sharing a Sense of Urgency}

The essential skill for skilled strategic actors is an ability to frame "stories" to attract people for collaboration by engaging their belief, interest, and identity. At the same time, those stories become an instrument to induce particular actions against their rivals. These stories could be about meaning, and membership, as a part of questioning group identity. Telling someone about what to do is the essential frame, but it could

35 Fr. Yohanes Indrakusuma, "Interview on Komunitas Tritunggal Mahakudus"; Indrakusuma, Dipanggil Untuk Yang Luhur Dan Mulia, 23; Yohanes Indrakusuma, CSE, Kasih Setiamu Hendak Kunyanyikan (Cianjur: Pertapaan Shanti Bhuana, 2009).

36 Indrakusuma, Dipanggil UntukYang Luhur Dan Mulia, 357-358. 
happen only by those with high authority. Erving Goffman, a Canadian sociologist that well known for his contribution to symbolic interaction, differentiates between the natural framing and social framing according to the actor who plays in the framing. While in the natural framing, an actor has no specific intentions or certain purposes, in the social framing, an actor plays as a person with specific competency and becomes a determined agency. ${ }^{37}$ By holding a particular position, people will easily cooperate with a certain actor(s). However, people should always convince people for specific collaboration, including those in a particular position. For that reason, the skill to influence others by cultural framing is undeniable for a skilled strategic actor(s) ${ }^{38}$

In its engagement for the youth, there are three social framings: the threat of Protestant Churches, the sinful youth culture, and the invitation for the engagement of lay people in the evangelization. In several books published by KTM, they mentioned about the threat of Protestant Churches upon the Catholic Church. ${ }^{39}$ On several occasions, both in the formal meetings or in the informal chat, I hear the word "Gereja Tetangga" (The churches next to us). This word is a pejorative since the word points out the churches that aggressively influence the Catholic to convert to their communities. It is never clear which churches that doing that since there are many denominations out of the Catholic Church. In the course of this research, they do not have a big sentiment on Islamic community. It is different from the question of Protestantism, especially the Pentecostal community. Some words emerged when we were discussing the topic of Protestant Churches: very aggressive to attract people from other communities and has poor theological teaching.

They do not differentiate the Protestant from the Pentecostal Churches. Our discussion went to focus on the topic of the "influence of Protestant upon Catholic." In the interview, several members of this community raised the idea of the several factors in the Catholic Church that do not exist in the Protestant Church, such as Mary, Eucharist, and Confession. Furthermore, in their statute, they mention that every member of KTM should not join the liturgy of other Churches. This in-

37 Erving Goffman, Frame Analysis: An Essay on the Organization of Experience. (Harvard University Press, 1974), 188.

38 Fligstein and McAdam, A Theory of Fields, 51.

39 Yohanes Indrakusuma, Menggereja 'Ala' KTM, 3; Komunitas Tritunggal Mahakudus, Program Pembinaan Anggota Buku Pegangan I, 11. 
struction explicitly mentions about the sectarian and aggressive as the character of other churches. This instruction works as a warning to all KTM's members of the significant risk of engaging the fellowship within the non-Catholic community. The reason is that they could be inclined to have the life-values, beliefs, or attitudes that are not in line with the Catholic faith and could easily be contaminated by the teachings that are contra to the Catholic teachings. ${ }^{40}$

Another framing is sinful youth culture. In the "Pedoman Hidup" book (the book on life guidance), they mention,

Precisely in the middle of massive apostasy, in which people openly deny God and disparage His laws, it is a great blessing for us to experience the love of God that transcends all understandings. Within the uncertainty and chaos of our world, it is a truly great gift that KTM members may encounter life full of peace and happiness. ${ }^{41}$

The third framing is the framing that this is a time for laypeople to work on evangelization effort. Indeed, it is not a new element of the Catholic Church, but as the explicit proclamation of the community and the evangelization program is a distinguished factor. KTM provides a new framing of evangelization. KTM prefers to have another kind of evangelization through personal engagement that they called as direct evangelization. ${ }^{42}$

These framings (the threat of Protestant Churches, the sinful youth culture, and the invitation for the engagement of lay people in the evangelization effort) play as the reason why these youth need to join KTM. By doing so, they intentionally say, "Indeed, it is good for you to be a Catholic, but it is you need another commitment, and KTM could help you to be a real Catholic."

\section{Set a Communal Agenda}

A skilled strategic actor(s) needs to convince people to follow a particular agenda as their interests. Therefore, they reach their goal when others accept their framework. They receive this concept as represent-

\footnotetext{
40 Fr. Yohanes Indrakusuma, "Interview on Komunitas Tritunggal Mahakudus."

41 Yohanes Indrakusuma, Pedoman Hidup Komunitas Tritunggal Mahakudus, 2014.

42 Yohanes Indrakusuma, Menggereja 'Ala' KTM, 25-26.
} 
ing their interest. This situation enables them to perform their agenda. ${ }^{43}$ There are four programs in which KTM able to set a collective interest: annual Youth Spiritual Camp, weekly cell meeting, Catholic Revival, and the KTM Youth Day.

The first, the annual youth spiritual camp, has already become an agenda for the youth cell community. The supporting group for this camp came from the youth cells from other places in Indonesia. Besides the committee from Surabaya and Malang, several KTM members from Semarang, Jakarta, Jember, Bali, and Makassar join them. They need to pay transportation and spend several days or even weeks to accompany the participants of the camp. In case they could not pay the transportation, they could ask for help from the adult members of KTM in each city. It is not an obligation for them to join the committee, but it has already become a need. In one of my discussions, one of them said, "As far as I can, I will support this camp since this camp helped me and will also useful for them." This camp is not merely camp, but this is the most effective tool to attract youth to join the community. Most f KTM youth members encountered KTM from the camp.

The second, KTM convince its members to join the weekly cell meeting. They explained how important these cell meetings. They said, "I dedicate the hour in a week for cell meetings. For these five years, I always join the cell meeting every Friday at 8 p.m; it seems that this is a family for me, so the cell meeting is a family bonding time; it is similar to dating so that we need to do it routinely to have a closer relationship." Most of them said that the sharing session is essential moment since, within this session, they could support each other and learn from each other. There are always at around $75 \%$ of members attend the weekly meeting. KTM convinces them that this cell meeting is essential for their religious life because these agenda serve their interests. Several members mentioned their cell as their second family because they feel that the brotherhood and sisterhood. It means that KTM successes to convince them the importance of cell meetings. This feeling is vital since many of them stated that they do not have active participation in their Parish. KTM could raise their sensitivity to live the Catholic faith. While they do not have the interest to join the routine religious activity, they do the best to attain the cell meeting. 
The third, even though they did not become the primary support of the Catholic Revival, but there is the essential participation of the KTM members. The youth members of KTM support this five-yearly Catholic Revival by sharing the tickets in order to reach their target, 7000 attendees. They also work to prepare the moment, either as a part of the performance or part of the supporting team. They had their confession a week before the Catholic Revival. They believe that their sin could make the event fail. Participating on the Catholic revival is not an obligation for Catholic, but KTM convinces people to regard it as an obligation. This Catholic revival is also a tool to attract people to join KTM, and these youth members are happy to support it as their common interest.

The fourth is the KTM Youth Day. KTM Youth Day is a five-yearly event in which all youth KTM members meet to each other for four days. They had already done four KTM Youth Day in 2000, 2005, 2010, 2015. In 2020, they will hold the fifth KTM Youth Day. For that moment, they do open recruitment to be the committee for this event. They also do fundraising by selling several items. They sell food, beverage, Christmas parcel, honey, softens, branded shoes, and bags. It is not an obligation for them to support this event, but as a community, they work for the program as theirs.

\section{Promoting New Insight in an Established Structure}

Each Skilled Social Actor has a role to promote new insight within an established social structure. Fligstein and McAdam explained this concept as brokering. In the brokering process, skilled social actor simultaneously keep their different identities and present themselves as neutral in a particular situation. Therefore this strategic works within two steps. The first, they act as an actor to mediate the interests of others. While the second, the strategic actor(s) actively promote their distinct identity and invite others to join them in the community. This step of making self-identification is a process that enables a social actor to keep the peace and deny this field from collapse. The core value of this brokering is to convince others that they did not drive to the narrow self-interest but instead fighting to reach a communal solution. ${ }^{44}$

KTM negotiated to have the recognition of the Catholic Church. From the in-depth interview, respondents find that people are still questioning whether or not this community is a Catholic Community. Socio${ }^{44}$ Ibid., 51-52. 
logically, there is a social instrument to link the resource mobilization and the social movement. This social instrument is known as a collective identity. Francesca Polletta and James M. Jasper, on their study about collective identity and social movements, explain collective identity as personal understanding, meaning, and affective connection toward specific groups, action, or society. It has a relation with a communal status that usually different from personal identity, and even this collective identity is a part of personal identity formation. An outsider could define it, but it could also rely on the personal acceptance of a particular social imagination. These collective identities could be conveyed in a specific name, story, communal symbol, particular habit, or communal attire. ${ }^{45}$ KTM has several tools to promote their communal identity:

1. They always have a brown costume when they are doing a program. This costume links them to the special attire for CSE priests and Putri Karmel nuns.

2. They shout this motto in every cell meeting, "KTM Penginjil .... Bangkit... bergerak.... Wartakan!" ("Evangelize KTM ..... rise.... move .... Proclaim.") This yell is a part of their meeting to raise their spirit as a community of evangelization.

3. The story about the ability of Fr. Yohanes, CSE priests, and Putri Karmel nun to cope with several problems with exorcism or deal with the problem of Magic raise their authority. Telling the same story over and over again in various activities increases the authority of this group.

\section{A Smooth Influencing Action}

On his way to receive the social acceptance, Skilled Social Actor engage a smooth approach. It is impossible to achieve social acceptance when an action serves only a need of Skilled Social Actor. SAFs theory used the term robust action that refers to single actions that can be understood from several perspectives. A particular action could serve double meanings. ${ }^{46}$ Traditionally, robust action means "noncommittal action that keeps future of action open in strategic context opponents are trying

45 Francesca Polletta and James M Jasper, "Collective Identity and Social Movements," Annual Review of Sociology 27, no. 1 (2001): 285.

46 John F Padgett and Christopher K Ansell, "Robust Action and the Rise of the Medici, 14001434,” American journal of sociology 98, no. 6 (1993): 1263. 
to narrow them." ${ }^{47}$ In this condition, the identity of a broker is ambiguous. People from different groups could have a different interest in the broker. A skilled strategic actor needs to maintain their multiple identity's attributions since the double communities could accept them. ${ }^{48}$ When a skilled actor appears as strictly different from the incumbent, the incumbent will easily notice them and quickly against them, but at the time when presenting themselves as open to the need of others, others could easier to find a negotiation with them. ${ }^{49}$ In this context, the skilled actor works as the information source to build the coalition.

The Catholics in Indonesia have not achieved one word regarding the Charismatic community. Several doubts about whether or not the Charismatic, including KTM, really Catholic. This doubt discussed in a book on Charismatic by a Jesuit Priest entitled "Mungkinkah Karismatik Sungguh Katolik" (Is it possible to have Charismatic as a real Catholic). ${ }^{50}$ Desi Ramadani explored the Catholic teachings and also the historical aspect of CCR. Despite its advanced study on this topic, this book is a reaction to the doubt among Catholics on whether or not charismatic is Catholic. Ramadhani convinces his readers that charismatic has its background in the Catholic teachings. He raises three questions on "Why is charismatic loved, but at the same time hated?", "Why is charismatic often suspected of infiltrating non-Catholics teaching into the Catholic tradition?", "How can somebody become more involved in charismatics and, at the same time, grow in a Catholic identity?"51 These questions come from the reality that the involvement of the charismatic movement in the Catholic Church in Indonesia is still questionable. However, the fact that KTM has CSE and Putri Karmel raise their authority as a Catholic community. Within this context, KTM could achieve certain acceptance since they could avoid any doubt on the Catholic identity of this community.

47 John F Padgett and Walter W Powell, “The Problem of Emergence," The emergence of organizations and markets (2012): 24.

48 Ibid.

49 Neil Fligstein and Doug McAdam, A Theory of Fields (Oxford University Press, 2015), 52.

50 SJ Deshi Ramadhani, Mungkinkah Karismatik Sungguh Katolik? (Kanisius, n.d.).

51 Ibid., 43. 


\section{Toward a Theology of Engagement}

In 1987, KTM was nothing, but nowadays they have contribution in the Catholic Church in Indonesia. They did politic of recognition in order to initiate a new initiative of living the Catholic faith. In the perspective of SAFs, they are running for a position within the Catholic Church, especially in engaging the participation of the youth in the evangelization process. KTM reaches the voluntary participation of the youth because they provide the youth with a field of action. KTM did not receive it for granted since there were several resistances either from the hierarchy of the Church or from the CCR in Indonesia.

The study of Komunitas Tritunggal Mahakudus is a study about social engagement. Members of this community do not only follow the Catholic faith in general, but they prefer to join the deeper involvement in the evangelization work. Indeed, there is a critic toward this community, especially that they have a community sentiment toward the Protestant and Pentecostal Churches. However, as a process of doing theology, Fr. Yohanes able to build a system of social engagement. His works are not exclusively for enriching laypeople with religious life, but also providing them with a field of action. Instead of living a personal religious life only, they reinforce their faith with personal involvement in the evangelization.

As a process of doing theology, Fr. Yohanes supports this community with a concept that accommodates people in the process of communal engagement. Within this context, KTM reached certain in the Catholic Church. The SAFs theory helps us to understand that there is a recognition process before this community achieves a voluntary involvement. Within this study, there are at least four steps on doing theology of engagement: (a) A Social framing - A clear communal goal; (b) Agenda-setting - Ensuring others that their works accommodate a sharing interest; (c) Brokering - Strengthening this community with enthusiasm; (d) Robust Action - Proposing new actions smoothly.

Theology of engagement is an instrument to have a voluntary involvement among the laypeople, including the youth. As Pope John Paul II wish to have a newness in expression, fervor and methods in the evangelization, KTM implements new social engagement that achieve youth acceptance and voluntary involvement. Furthermore, as Pope Francis said about youth both object and subject of evangelization, KTM youth members do not only works as receivers of evangelization, but also as ac- 
tor of evangelization work. Fr. Yohanes and his communities do not only share them with any information or teaching about the Catholic Church, but also engages them as evangelizer. KTM emphasizes that the Catholic Church is not only about the hierarchy but also laypeople, including the youth. Either in the Oikos Evangelization or Ad Gentes Evangelization, the youth participation becomes the key factor of the whole community.

KTM social engagement provides us with a method that enables us to raise the participation of youth in the works of evangelization. The increasing number of KTM memberships becomes a piece of evidence that their method is applicable. However, as promote by the SAFs theory, it is a must for a social structure to always build and rebuild its structure. A social structure always has a challenge to perform itself in the middle of changing situation.

\section{Bibliography}

Angelika Dewi Wijayanti Supriyanto, May 18, 2018.

Chesnut, R Andrew. Competitive Spirits: Latin America's New Religious Economy. Oxford University Press, 2003.

Cho, Yong-gi, Harold Hostetler, David Yonggi Cho, and Yong-Gi Cho. Successful Home Cell Groups. Logos International, 1981.

Denig, Stephen J, and Anthony J Dosen. "The Mission of the Catholic School in the Pre-Vatican II Era (1810-1962) and the Post-Vatican II Era (19651995): Insights and Observations for the New Millennium." Catholic Education: A Journal of Inquiry and Practice 13, no. 2 (2009).

Deshi Ramadhani, SJ. Mungkinkah Karismatik Sungguh Katolik? Kanisius, n.d.

Finke, Roger, and Rodney Stark. The Churching of America, 1776-2005: Winners and Losers in Our Religious Economy. Rutgers University Press, 2005.

Fligstein, Neil. "Social Skill and the Theory of Fields." Sociological theory 19, no. 2 (2001): 105-125.

Fligstein, Neil, and Doug McAdam. A Theory of Fields. Oxford University Press, 2015.

A Theory of Fields. Oxford University Press, 2015.

— . "Toward a General Theory of Strategic Action Fields." Sociological theory 29, no. 1 (2011): 1-26.

Fr. Yohanes Indrakusuma. "Interview on Komunitas Tritunggal Mahakudus," August 8, 2019. 
Goffman, Erving. Frame Analysis: An Essay on the Organization of Experience. Harvard University Press, 1974.

Indrakusuma, Yohanes. Dipanggil Untuk Yang Luhur Dan Mulia. Cianjur: Pertapaan Shanti Bhuana, 2009.

Komunitas Tritunggal Mahakudus. Latihan Pelayan Sel Komunitas. Cianjur: Sekretariat KTM Pusat, n.d.

—. Program Pembinaan Anggota Buku Pegangan I. Komunitas Tritunggal Mahakudus, n.d.

McCallion, Michael J, and David R Maines. "Representations of Faith and the Catholic New Evangelization.” New Theology Review 22, no. 1 (2009).

Padgett, John F, and Christopher K Ansell. "Robust Action and the Rise of the Medici, 1400-1434." American journal of sociology 98, no. 6 (1993): $1259-1319$.

Padgett, John F, and Walter W Powell. "The Problem of Emergence." The emergence of organizations and markets (2012): 1-29.

Peterson, Anna L, and Manuel A Vásquez. "The New Evangelization in Latin American Perspective." CrossCurrents (1998): 311-329.

Polletta, Francesca, and James M Jasper. "Collective Identity and Social Movements." Annual review of Sociology 27, no. 1 (2001): 283-305.

Ralph W. Neighbour, Jr. Ke Mana Kita Harus Melangkah? Yayasan Metanoia Publishing, 1997.

Stoll, David. Is Latin America Turning Protestant?: The Politics of Evangelical Growth. Univ of California Press, 1990.

VI, Paul. "Evangelii Nuntiandi ('On Evangelization in the Modern World').” Apostolic Exhortation (1975).

Yohanes Indrakusuma. Menggereja 'Ala' KTM,. Cianjur: Pertapaan Shanti Bhuana, n.d.

Pedoman Hidup Komunitas Tritunggal Mahakudus, 2014.

Yohanes Indrakusuma, CSE. Kasih Setiamu Hendak Kunyanyikan. Cianjur: Pertapaan Shanti Bhuana, 2009.

"Komunitas Tritunggal Mahakudus | Our Vision \& Spirituality." Accessed March 12, 2019. http://www.holytrinitycarmel.com/our-spirituality/.

Statuta Komunitas Tritunggal Mahakudus. Cianjur: Komunitas Tritunggal Mahakudus, n.d. 
